\title{
A vállalati vagyon és a finanszírozás összefüggései a vagyonértékelés szempontrendszere szerint
}

\author{
F. BuZÁs, S. KISS, I.MEZŐ \\ Debreceni Egyetem, Gazdaságtudományi Kar, buzas.ferenc@econ.unideb.hu \\ Biblio-Markt Kft.info@biblio.hu
}

Absztrakt. A finanszírozási forrásokhoz való hozzáférés a vállalati szféra versenyképességének kulcstényezőjét jelenti, kedvező feltételek mellett nem csak gazdasági növekedést és konjunkturális hatásokat eredményezhet, hanem közvetetten a társadalmi folyamatokat is pozitívan befolyásolja. A cikk elsô részében a vállalati finanaszírozás fontosabb jellemzőit tekintjük át gazdasági és társadalmi összefüggésben, törekedve a finanszírozási viszonyok átfogó szemléjére. A cikk második részében a finanszírozás szabálykeretét tekintjük át a vonatkozó nemzetközi és hazai előírások tárgyalásával, a harmadik részben pedig a vállalati finanszírozás hátterét elemezzük a vagyonértékelői gyakorlat és szempontrendszer alapján.

Abstract. The availability for financial sources can be the key factor of competitiveness of enterprises. Under favourable conditions it can result in not only economic growth and conjunctural effects but indirectly it also has a positive influence on social level as well. In the first part of the article we make an overview on enterprise financing in both social and economic context and try to give an overall concept. In the second part we analyse the framework of financing, discuss the national and international specifications of financing, and finally, in the third part we analyse the background of enterprise financing based on the principles of asset appraisal.

\section{Bevezetés}

A XIX.-ik század közepe táján William Gladstone egykori brit miniszterelnök a finanszírozás szerepét a gazdaság számára a következőképpen fejezte ki: „A finanszírozás egy ország gyomrát jelenti, amin keresztül az összes többi szervnek biztosítja a működését" (1). Ha a vállalkozások és ezen belül a mikro-, kis- és közepes vállalkozási szektor jelentőségét nézzük foglalkoztatás- és hozzáadott-érték növelés vagy innováció tekintetében a legrugalmasabb gazdasági intézményi hátteret jelentik egy adott ország tekintetében. Ha a finanszírozást - mint a vállalati versenyképesség egyik kulcstényezőjét tekintjük - az látható, hogy a MKKV kategória kevésbé preferált a pénzintézetek által, melynek alapvető oka a finanszírozási kockázatokban rejlik.

A mikro-, kis- és közepes vállalkozások finanszírozásának több módozata alakult ki, ami országonként, igen eltérő formában van jelen. A nyugat- és közép-európai országokban - így Magyarországon is - a finanszírozásban és a vállalati pénzügyi müködtetés területén meghatározó szereppel bírnak a kereskedelmi bankok, lízingcégek, és a TAM/BAS programok (nehéz helyzetben levô vállalatok szerkezetátalakítása/Üzleti tanácsadási szolgáltatás). A déli-európai országokban valamivel 
sokszínűbb és részben összetettebb, a fentiek mellett gyakori finanszírozási forma még a kereskedelmi bankok közbeiktatásával megvalósuló KKV programok, a szakosodott mikrohitelezés, üzletpolitikai intézkedések (u.n. Policy Dialogue pl. önkormányzatok bevonásával) [2].

\section{A vállalati finanszírozás helyzete a gazdasági válság tükrében}

A 2008-as gazdasági válság alapjaiban rázta meg mind a finanszírozást eszközlő mind a finanszírozott gazdasági szervezeteket. A lelassult gazdasági növekedés évtizedes trendet tört meg és a felszínre kerülő problémák a növekedéssel kapcsolatos gazdasági paradigmák újraértékelését tették szükségszerűvé [3]. A legutóbbi világgazdasági válság előtt jóval, már a '70-es években is felmerültek figyelmeztető nézetek (többnyire az évtized elején kialakult olajválság kapcsán) arról, hogy a világgazdaság szereplőinek be kellene látni, hogy a növekedésnek határai vannak, a növekedés újraértelmezése pedig egy új gazdasági mechanizmus megalkotásával lehetséges [4, 5], de ezeket a racionalitásokat időnként felülírják a rövid távú szemléletet előtérbe helyező szűk látókörű nézetek. Minden válságot követő időszakban a gazdaság szereplőinek újrafinanszírozása a kilábalás elsődleges feltételét jelenti [6]. A kis- és közepes vállalkozásoknak a válságból való kilábalásban kiemelkedő szerepük van, mivel reakcióidejük rövidebb, gyorsabban tudnak reagálni, mind a munkaerőpiaci mind a finanszírozási környezet változásaira és támogathatják a konjunktúra folyamatokat [7].

\begin{tabular}{|c|c|}
\hline Termelés és piac & Eszköz (vagyon) és Technológia \\
\hline $\begin{array}{l}\text { - piaci lehetőségek szúkülése } \\
\text { - a verseny erősödése, árképzési } \\
\text { (áralku) limitek } \\
\text { - beszállítók tranzakciós erejének } \\
\text { csökkenése } \\
\text { - a nagy vevők tranzakciós (alku) } \\
\text { erejének növekedése }\end{array}$ & $\begin{array}{l}\text { - beruházási projektek restrikciója, } \\
\text { leállítása } \\
\text { - új technológiai eljárások } \\
\text { bevezetésének leállítása }\end{array}$ \\
\hline Humán erőforrás & Pénzügyek \\
\hline $\begin{array}{l}\text { - } \begin{array}{l}\text { foglalkoztatás stabilizálódása vagy } \\
\text { csökkenése }\end{array} \\
\text { - bérszínvonal stabilizálódása vagy } \\
\text { csökkenése } \\
\text { - személyi állomány, tovább- } \\
\text { képzések költségeinek csökkenése }\end{array}$ & $\begin{array}{l}\text { - } \quad \text { ár- és árbevétel csökkenés } \\
\text { - likviditási problémák } \\
\text { - } \quad \text { adósságnövekedés, halmozás } \\
\text { - külső források felvételének } \\
\text { korlátozódása ("fekete listára” } \\
\text { kerülés) }\end{array}$ \\
\hline
\end{tabular}

1.táblázat: Tipikus jelenség és magatartás a vállalati szférában gazdasági krízis esetén [7]

\section{A vállalati finanszírozás helyzete a vállalati szférában - a felmérések tükrében}

A Világbank egyik munkacsoportjának (Enterprise Analysis Unit) tanulmánya alapján végzett becslések szerint az elkövetkező másfél-két évtized során kb. 600 millió munkahelyet szükséges létesíteni, annak érdekében, hogy - elsősorban a fejlődő országokat fenyegető, de a fejletteket is érintő 
- társadalmi feszültségek megelőzhetők legyenek. Mivel a foglalkoztatásban meghatározó szerepe van a KKV szektornak, előrejelzések szerint 365-445 millió mikro-, kis- és közepes vállalkozás létrehozásával biztosítani lehetne a becsült foglalkoztatási igényt. Az ehhez szükséges finanszírozási összeg globális szinten 2,1-2,6 trillió (trillió=ezer milliárd) dollárra becsülhető [8].

A tanulmány globális szinten készült és célja az volt, hogy a MKKV szektor finanszírozási hátteréről részleteket deríthessenek ki, melynek alapján cselekvésprogram kidolgozható. A felmérés teljes körü volt, viszont a továbbiakban többnyire csak Magyarországra vonatkozó adatokat közöljük.

A felmérésről: az eredményeket, 2013-ban zárták, Magyarországról összesen 310 (186 kis-, 75 közepes, és 49 nagy) vállalkozás került a mintába, ebből 108 kiskereskedelmi, 98 feldolgozóipar és 104 egyéb szolgáltatást végző cég volt, területileg pedig 136 volt a közép-, 85 a nyugati, és 89 a keleti régióból. Összehasonlítási alapként az OECD magas jövedelmű országainak átlagát közöljük.

\begin{tabular}{|l|c|c|}
\hline MUTATÓRENDSZER & $\begin{array}{c}\text { Magyar- } \\
\text { ország }\end{array}$ & $\begin{array}{c}\text { OECD } \\
\text { magas jöved. }\end{array}$ \\
\hline Banki hitellel rendelkező cégek aránya & 37,3 & 46,3 \\
\hline Fedezetet igénylő hitelek aránya & 77,3 & 64,8 \\
\hline Hitelt nem igénylő cégek aránya & 51,7 & 60,2 \\
\hline Beruházásokhoz banki hitelt igénylők aránya & 22,6 & 30,5 \\
\hline Múködőtőkét szállítói hitelből fedezők aránya & 12,5 & 11,4 \\
\hline Működőtőkét banki hitelből fedezők aránya & 25,3 & 33,1 \\
\hline \multicolumn{1}{|c|}{ Cégek átlagos életkora } & 14,2 & 18,8 \\
\hline \multicolumn{2}{|c|}{0,7} & 4,6 \\
\hline Éves növekedési ráta az értékesítésben & 33,9 & 55,2 \\
\hline
\end{tabular}

2. táblázat: A vállalati finanszírozás egyes jellemzői Magyarországon és az OECD magas jövedelmú országaiban [8]

Az eredményeket tekintve a hazai és a magas jövedelmű OECD országok közötti eltérés szembetűnő, de nem annyira jelentős, viszont jól tükrözi a hazai finanszírozási rendszer némi elmaradottságát ezekhez képest. Egy további elemzés a KKV szektor finanszírozási lehetőségeit és ezzel kapcsolatos preferenciáit vizsgálta. A felmérés rámutatott arra, hogy az eszközberuházás valamint a készlet és múködőtőke finanszírozási igénye meghatározó a KKV szektorban. Kisebb jelentőséggel bír a kötelezettségek visszafizetése, a szolgáltatás és termelésfejlesztés valamint a munkaerő képzésével vagy kölcsönzésével kapcsolatos finanszírozási cél. 


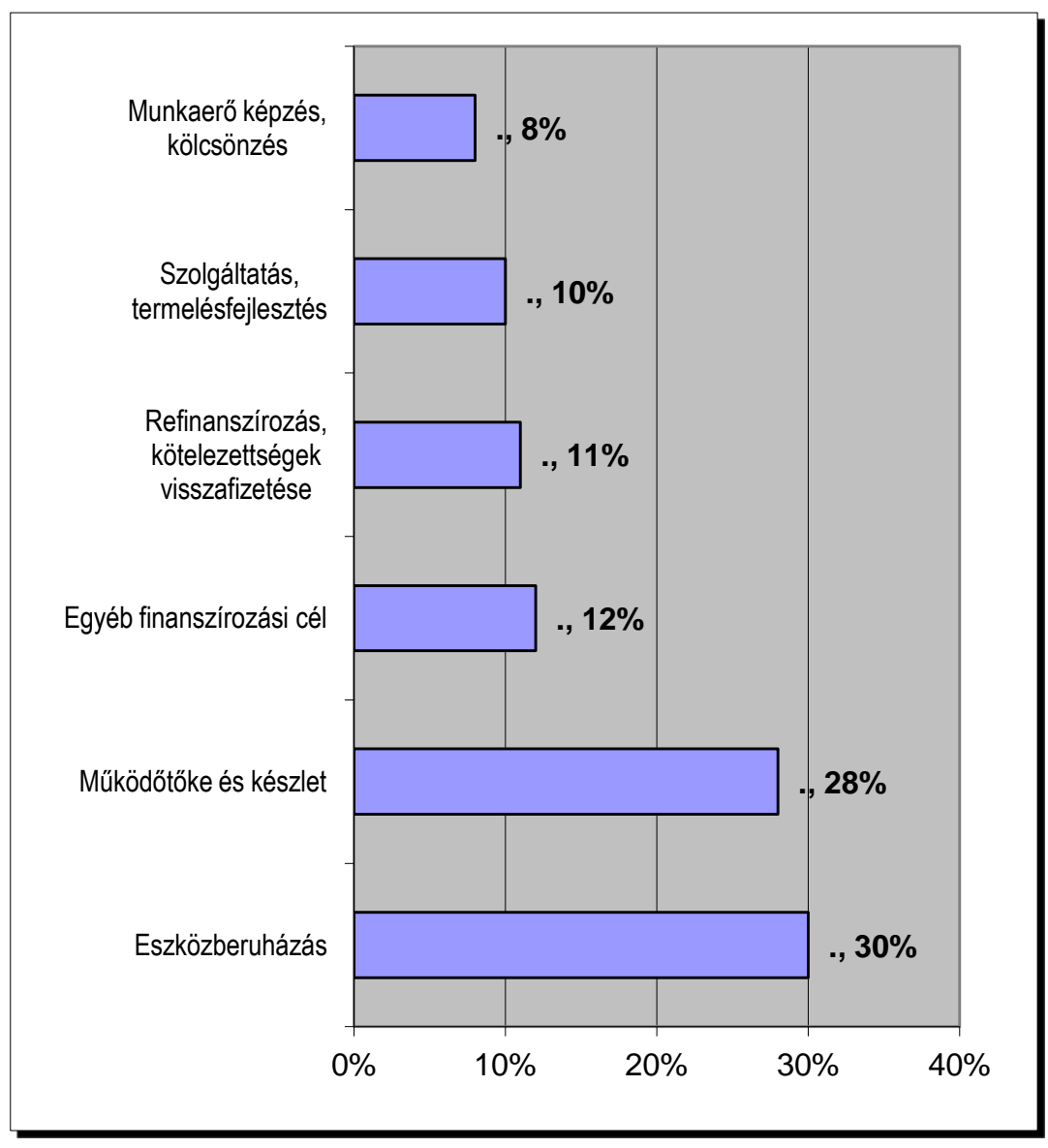

1. ábra: A vállalatok külső finanszírozási céljai az EU-28 országaiban [10]

Ugyanebben a felmérésben vizsgálták többek között a finanszírozási típusok relevanciáját. A három leginkább kiemelt finanszírozási forma banki hitelhez, a rendelkezésre álló hitelkerethez valamint a lízinghez és a bérlethez kapcsolódik. Közepes relevanciájú a pályázatokhoz, támogatott hitelekhez és a kereskedelmi hitelezéshez köthető finanszírozás. A legkisebb relevanciával a faktoring, a hitelbiztosíték és az egyéb finanszírozási mód rendelkezik (2. ábra). 


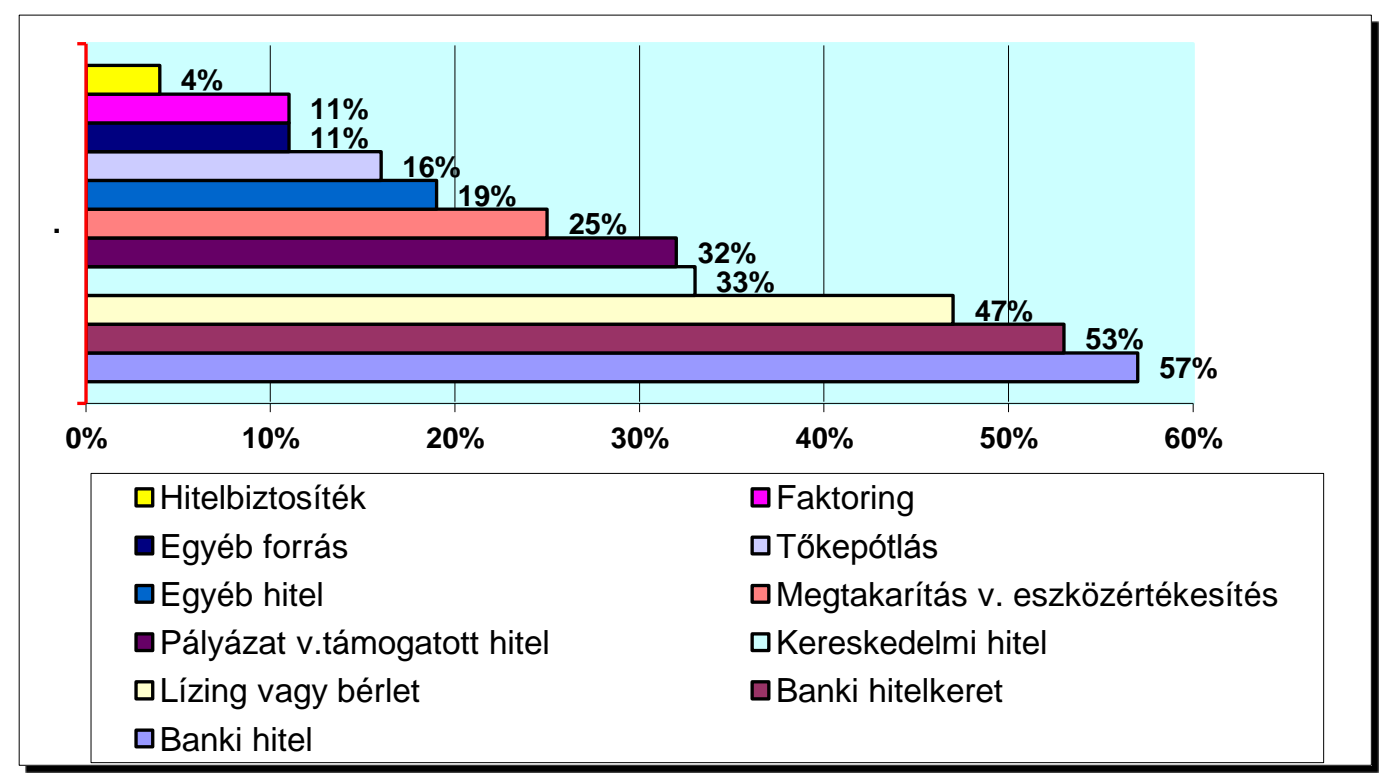

2. ábra: A finanszírozási típusok relevanciája az EU-28-ak országaiban [10]

\section{A finanszírozás szabálykeretei - a vonatkozó nemzetközi és hazai előírások tükrében}

A finanszírozás szabálykereteit nemzetközi egyezmények, előírások határozzák meg, melyek a pénzés hitelintézetek tevékenységére vonatkozóan mérvadóak, de a szabályozások révén közvetlen hatást gyakorolnak a vállalatok finanszírozására is. Az európai pénzpiacokat valamint a pénz- és hitelintézetek tevékenységét alapvetően két intézmény szabályozza, az egyik az Európai Bankhatóság (European Bank Authorty - része a Pénzügyi Felügyeletek Európai Rendszerének) amely egy független uniós hatóság de ugyanakkor elszámolással tartozik az Európai Parlamentnek, az Európai Unió Tanácsának és az Európai Bizottságnak. Az EBH fő feladata, hogy kötelező érvényű technikai standardok és iránymutatások elfogadása révén hozzájáruljon a bankszektorban az egységes európai szabálykönyv megteremtéséhez, melynek célja a harmonizált prudenciális szabályok közös készletének biztosítása EU-szerte a pénzügyi intézmények számára. A hatóság fontos szerepet játszik a felügyeleti gyakorlatok közelítésének előmozdításában is, biztosítva ezzel a prudenciális szabályok harmonizált alkalmazását. Az EBH megbízásába tartozik az uniós bankszektor kockázatainak és gyenge pontjainak értékelése is, különösen a rendszeres kockázatértékelési jelentések és páneurópai stressztesztek révén [11].

A másik meghatározó szerv a Bázeli Bankfelügyeleti Bizottság (Basel Committee on Banking Supervision - formális nemzetek feletti hatásköre nincs, ezért csak ajánlások, szabályozási keretek formájában határozza meg az egységes normákat és a hitelintézetek nemzetközi felügyeleti gyakorlatát). A Bázeli Bizottság által 1988-ban megjelentetett és több mint 100 ország által deklarált Bázel I. tőkeegyezmény a hitelkockázat kezelésére, valamint a tőkemegfelelés fogalmának, illetve a banktőke tartalmának definiálására fókuszált. Az egyezmény a '90-es évek második felében a piaci kockázatokkal bővült. 1999-ben jelent meg a Bázel II egyezmény, mely radikális változásokat 
tartalmazott a korábbiakhoz képest, egyrészt a szabályozás beemelte a működési kockázatot is a tőkével fedezendő kockázatok közé; másrészt a kockázatok kezelésében és a minimális tőkeszükséglet meghatározásában nagyobb teret engedett a bankoknak: bizonyos kritériumok teljesítése esetén az intézmények a jogszabályban rögzített tőkeszámítási metódus helyett választhatják saját adataikon, tapasztalataikon nyugvó matematikai és statisztikai modellek által kalkulált tőkemértéket, adott feltételek mellett [12]. A Bázel III tőkeegyezmény megjelenését a válság indukálta és jelenleg is heves viták övezik, középpontjában az intézmények likviditása és a szigorúbb tőkekövetelményi szabályok állnak.

A vállalati hitelezés során a hitelköltségeket a Bázeli elvek szerint adott formula segítségével kell kalkulálni. A szabályozási követelmények változásának hatása a hitelköltségekre - mint a hitelköltségek árazásának metodikája - az alábbi formulával szemléltethető [13]. Ebben a legfontosabb kritérium az, hogy az adózás utáni hitelkamat rátája fedezi-e az adózás utáni hitelkamat finanszírozási költségeit, beleértve a kezelési költségeket is, azaz:

$$
L^{*}(1-t) \geq\left(E^{*} \text { re }\right)+\left(\left(D^{*} r d\right)+C+A-0\right) *(1-t), \quad \text { ahol: }
$$

$\mathrm{L}=$ a hitel tényleges kamatrátája, beleértve a többi felszámított díj annualizált értékét

t = a banki adó-ráta mértéke

E = saját tőke aránya a felvett hitelhez viszonyítva

re = elvárt megtérülési ráta - saját tőke határhaszna

$\mathrm{D}=\mathrm{a}$ betéti és hitelkamat aránya $-\mathrm{E}$

rd = a D tényleges marginális kamatrátája, beleértve a forrásszerzés közvetlen költségeit (pl. a fiókhálózat költségei)

C = a hitel szórása, egyenlő a valószínűségi együtthatóval súlyozott várható veszteséggel

A = a hitellel kapcsolatos adminisztrációs és egyéb kiadások

$\mathrm{O}=\mathrm{a}$ hitellel kapcsolatos egyéb jövedelmek és kiadások

A Bázel III tőke- és likviditási egyezmény elfogadásával a pénzügyi-hitelezési szektor stabilitása egyértelműen növekedett viszont a finanszírozási igény oldaláról a vállalati (és lakossági) szféra csak közvetett haszonélvezői a folyamatnak ill. szabályozásnak, mivel a biztonság és stabilitási kritériumok betartása növeli a hitelezési költségeket, amit a pénz- és hitelintézetek áthárítanak. Becslések szerint a szigorúbb előírások Európában 18 százalékponttal fogja növelni a hitelek költségét, az Egyesült Államokban pedig 28-al [14].

\section{A finanszírozás kérdései vagyonértékelői szempontok alapján}

A Bázel III előírásoknak megfelelően a pénz- és hitelintézetek 2014. január 1-jétől Nemzetközi Pénzügyi Beszámolási Standardok (IFRS) alapján konszolidált beszámolót kell készíteniük az IFRS 10, IFRS 11, IAS 28 és az IAS 39-es szabályok figyelembevételével. A bankok a számviteli és az összevont 
alapú felügyeleti konszolidációba valamennyi leányvállalatukat teljeskörűen kell bevonniuk, azaz a számviteli és a tőkekövetelmény számításához kapcsolódó konszolidációs kör között nem lehet eltérés, részlegesen konszolidált tételek nem lehetnek.

A vagyonértékelés a hitelintézetek megbízásából végzett és a legtöbb esetben külső független szolgáltatók által megvalósított gazdasági, műszaki és jogi szempontokat figyelembe vevő értékelői tevékenység. A vagyonértékelők a bankok belső tőkemegfelelés-értékelési folyamatában és a kockázatkezelésben egyaránt kiemelt szereppel rendelkeznek mind a hitelezési és tartalékképzési folyamatok megfelelő mértékű hatékony felmérésben, mind a folyamatos ügyfél- és fedezetmonitoringban, de a kockázatok azonosításában is - amennyiben a partnerbank őket erre felhatalmazza. A legfontosabb szerepük viszont a kockázatokat csökkentő biztosítékok értékelésében áll.

A fedezetek befogadási, vagy aktualizált érték-megállapítása történhet forgalmi vagy piaci értéken, likvidációs értéken vagy hitelbiztosítéki értéken és szerződés szerinti értéken. A Bankok a fedezeti értéket a fedezet típusától, a megtérülési tapasztalatoktól, illetve egyéb tényezőktől függően meghatározott diszkontok figyelembe vételével határozzák meg. Ez a megoldás biztosítja, hogy egy esetleges kényszerértékesítés során a nyilvántartott fedezeti érték és az elért megtérülés összhangban legyen egymással. Az értékelési metodika a - banki működési szabálykeretekhez hasonlóan - szintén nemzetközi előírások szerint történik. Az értékelési tevékenység szakmai jogosultsághoz kötött mely jogszabályban van rögzítve (ld. 25/2008. (IV.29) ÖTM rendelet valamint a 31/2009. (XI. 18.) ÖM rendelet). Az értékeléshez előírt szakképesítések és jogosultságok a következők: Ingatlanközvetítő és értékbecslő; Ingatlanvagyon-értékelő és közvetítő; EUFIM (Európai Felsőszintű Ingatlanszakmai Minősítés); Igazságügyi szakértő. Fontos kiemelni, hogy a nagyobb értékű vagyontárgyak értékelése során egyre jobban előtérbe kerül a szakértői teamek által végzett értékelés, az egyéni, személyre korlátozó feladatok egyre jobban háttérbe szorulnak. A megbízói érdekek magas színvonalú kiszolgálásához a korszerű technikai feltételek, eszközök, adatbázisok és szakembergárda megléte maholnap nélkülözhetetlenné válik.

$\mathrm{Az}$ értékelés elvi és módszertani alapjait Európai Értékbecslési Szabványok (European Valuation Standard EVS) tartalmazza, mely, Nemzetközi Szabványügyi Bizottság (International Valuation Standards Council - IVSC) által kidolgozott szabványoknak megfelelően lett kialakítva. Az értékeléssel kapcsolatos szabványokat az Európai Eszközértékelők Csoportja (The European Group of Valuers Association - TEGoVA) 2003-ban egy összefoglaló kötetben közölte, amit folyamatosan bővítenek és évente újabb kiadásban közölnek. Az értékelés jogszabályi alapjat és módszertani elveket az EVS szabványok előírásainak megfelelő 26/2005.(Vlll. 11.) PM rendelettel módosított 25/1997.(VIII.1.) PM rendelet és az 54/1997.(Vlll.1.) FM. rendelet tartalmazza.

Meg kell említeni, hogy a jogszabályok általános elvi és módszertani alapokat tartalmaznak, az alkalmazás terén viszont az értékelők számára egyéb szakmai eljárások módszertani alkalmazások eszközlése nem korlátozott, amennyiben megfelelően alátámasztottak és a megbízói elvárásoknak megfelelnek. Ezek elsősorban gazdasági és műszaki jellegű számítások, melyek a piaci környezet 
értékelésére, kockázatok és műszaki állapot becslésére pénzügyi-gazdasági számításokra vonatkoznak.

Tekintettel arra, hogy a hitelek legnagyobb része beruházással, eszközfinanszírozással, működéssel kapcsolatosak és a finanszírozó számára a legbiztonságosabb fedezetet elsősorban a hosszú távon értékálló eszközök (ingatlanok), másodsorban a rövidebb használati időtartamú eszközök (berendezések, gépek) jelentik, ezért a fedezetbe vonáskor ezek jönnek elsődlegesen számításba. Az értékelés kiindulópontját a forgalmi érték jelenti, melynek meghatározási módja az értékelési szabványokban (jogszabályokban) rögzített. Ennek megfelelően három megközelítésben lehetséges az érték levezetése: piaci összehasonlító alapon, újrapótlás költség elven, és hozam (jövedelemtermelés) elvén. A forgalmi értékből kiindulva határozzák meg a hitelfedezeti értéket, amely összhangban állhat a folyósított hitelösszeggel, továbbá megállapításra kerül a likvidációs vagy kényszerértékesítést lehetővé tevő legvalószínűbb érték is. A hozam (jövedelem) elvű értékelés során két módszertani eljárás is rendelkezésre áll, az egyik a jövedelem tőkésítésére (DC) épül a másik a diszkontált várható nyereségek összegéből (DCF) vezeti le az értéket. Mindkét esetben a tőkésítési vagy diszkont kamatlábhoz az adott pénz- vagy hitelintézet ajánlását veszi alapul az értékelő, adott szempontok alapján. A rátákban jelentés eltérés tapasztalható ingatlantípustól, az ingatlan földrajzi és közigazgatási elhelyezkedésétől, műszaki állapotától stb. egyéb adottságtól függően. A javasolt ráták általában hosszú időtávra szólnak az átmeneti kamat- és kockázati prémiumok ingadozását áthidalják. Az alábbiakban három jelzálogbank által alkalmazott ráták átlagát közöljük adott ingatlanszegmensre vonatkozóan.

\begin{tabular}{|l|c|c|c|c|}
\hline \multirow{2}{*}{} & \multicolumn{2}{|c|}{ Budapest } & \multicolumn{2}{c|}{ Vidék } \\
\cline { 2 - 5 } & Min. & Max. & Min. & Max. \\
\hline Irodai szegmens & $7 \%$ & $10 \%$ & $10 \%$ & $13 \%$ \\
\hline Kereskedelmi szegmens & $7 \%$ & $9 \%$ & $9 \%$ & $14 \%$ \\
\hline Turisztikai szegmens & $8 \%$ & $12 \%$ & $10 \%$ & $15 \%$ \\
\hline Ipari ingatlan, raktár, telephely & $9 \%$ & $12 \%$ & $10 \%$ & $15 \%$ \\
\hline
\end{tabular}

3. táblázat: Alkalmazott tôkésítési és diszkont ráták (Jelzálogbankok átlaga)

A finanszírozási gyakorlatban pénz- és hitelintézetektől illetve ezek hitelezési és ügyfélpolitikájától függően a folyósításra kerülő hitel mértékét különböző módon állapítják meg. Általában a forgalmi értékből levezetett hitelfedezeti érték a mérvadó, de előfordul a forgalmi érték alapján vagy a hitelfedezeti érték alatt un. likvidációs érték mértékéig folyósított hitelezés is. A különböző értékfogalmakat az Európai Értékelési Standardok (15), és ezzel harmonizáló 25/1997 (VIII. 1.) PM rendelet (a termőföldnek nem minősülő ingatlanok hitelbiztosítéki értékének meghatározására vonatkozó módszertani elvekről) részletezi. Az alábbiakban a különböző értékkategóriákat kívánjuk szemléltetni - adott feltételek mellett - egyes szakértői értelmezésekkel kiegészítve (ld. 16 sz. forrást). 


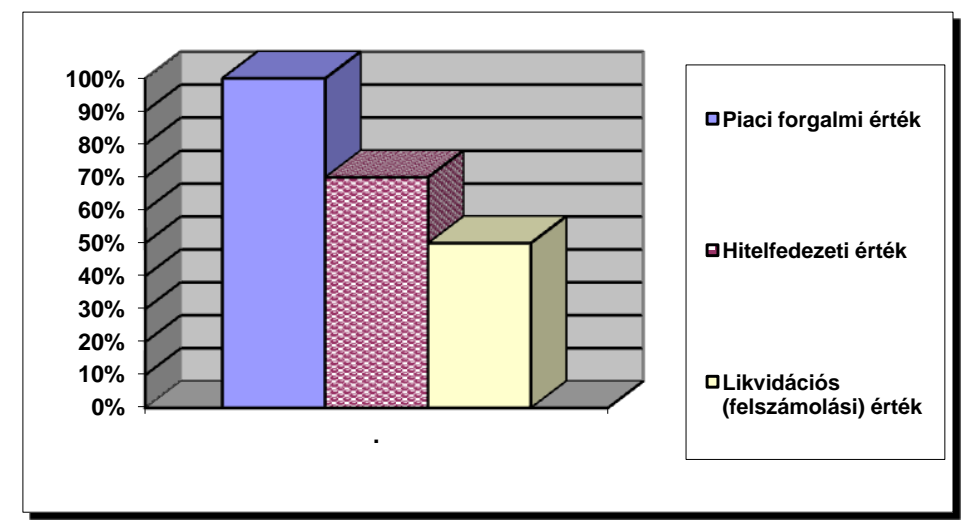

3. ábra: A fedezeti értékelés keretében alkalmazott értékkategóriák

A forgalmi érték alapjául általában a piaci összehasonlító értéket veszik alapul, de más módszereknek az egyszerű vagy súlyozott átlagát is figyelembe lehet venni, amennyiben megfelelően indokolt és szakmailag alátámasztott (az értékek helytelen, kellően nem dokumentált vagy szakmaiatlan összegzése vagy kombinálása gyakran ad alkalmat jogvitákra). A hitelfedezeti érték megállapítását a legtöbb pénzintézet külön szabályzatban rögzíti. A kiindulási alapot a 25/1997. (VIII. 1.) PM rendelet szolgáltatja, mely szerint: a hitelbiztosítéki érték valamely ingatlannak az óvatos becslés alapján meghatározott értéke. A hitelbiztosítéki (fedezeti) érték megállapításának alapja a piaci forgalmi érték.

Továbbá (a rendelet szerint): „A hitelbiztosítéki érték megállapítása során a jelzálog-hitelintézet által folyósított kölcsönök hosszú lejáratából származó sajátos kockázatokat, valamint az ingatlannak csak azon tulajdonságait és hozamait lehet figyelembe venni, amelyek várhatóan a jövőben bármely tulajdonost megilletnek”. Ennek megfelelően „a hitelbiztosítéki érték megállapítása során az értékelési eljárásoknál szokásosan elemzett kockázatok közül különös figyelmet kell fordítani:

a) az ingatlan hosszú távú értékállandóságának kockázatára;

b) a piaci adatok megbízhatatlansága miatti kockázatra;

c) az egyéb adatok megbízhatatlansága miatti kockázatra"

A jogszabály az ingatlanok értékelésére vonatkozik, viszont a „szokásjog szerint” a gyakorlatban az említett előírások más eszközök (pl. gépek, berendezések vagy más vagyontárgyak) értékelése során is alkalmazhatók, továbbá figyelemmel kell lenni arra is, hogy a termőföldre külön jogszabályok vonatkoznak.

A fedezetbe vonandó vagyontárgyakkal szemben támasztott értékelői követelményeket és az értéket befolyásoló tényezőket az értékelői tapasztalatok alapján az alábbiakban részletezzük álló- és mobil eszközökre vonatkozóan összefoglalva:

- tulajdonjogi rendezettség, tulajdonos(ok) beazonosíthatósága, megfelelően rendezett nyilvántartási dokumentáltság,

- ingatlanok esetében közvetlen és tágabb környezet jellemzői (társadalmi, gazdasági, természeti)

- az eszköz használatával kapcsolatos jogi tények dokumentáltsága (bérleti vagy lízing szerződés, karbantartási jogok, kötelezettségek, haszonélvezet stb.) 
- az eszköz használatával kapcsolatos gazdasági tények dokumentáltsága (jövedelemtermelő képesség: bevételek/kiadások egyenlege, alternatív költségek kalkulációja)

- az eszközök egyedi fizikai azonosíthatósága rendeltetésszerű használat feltételei mellett (nyilvántartás módja, értékei)

- az eszköz műszaki-technikai állapotának, paramétereinek felmérhetősége, vizsgálata - szükség szerint megfelelően dokumentációval ellátva (nyilvántartási kartonok, beüzemelési-karbantartási jegyzőkönyvek, gépkönyv stb.)

- az eszköz műszaki- technikai dokumentáltsága (váz- és műszaki rajzok)

- az eszköz pótlásának piaci viszonyai, körülményei (új, használt vagy avultatott állapot szerint árak, létesítési, beszerzési, beüzemelési költségek),

- az eszköz másodlagos piacának jellemzői (keresleti/kínálati viszonyok)

- alternatív hasznosítás fennálló feltételei és körülményei (amennyiben fennállnak - elemzés szükséges)

\section{Hivatkozások}

[1] Duisenberg, W.F (2001): The role of financial markets for economic growth". Economics Conference on The Single Financial Market: Two Years into EMU" organised by the Oesterreichische Nationalbank in Vienna.

[2] Kadocsa Gy. (2012): A hazai kis és közepes vállalkozások helyzete és fejlesztési lehetőségei. Vállalkozásfejlesztés a XXI. Században Budapest, Óbudai Egyetem-Szervezési és Vezetési Intézet $-\mathrm{K}+\mathrm{F}$ kutatócsoport.

[3] EBRD (European Bank for Recosntruction and Development) (2006): Micro, Small and Medium-sized enterprises strategy. Board of Directors. Bruxelles. 11-12.

[4] Lawrence D. (2014 ): The slumps that shaped modern finance. The Ecoomist 12 April 2014.

[5] Johnson H.G D. (1977 ): The New International Economic Order. Graduate School of Business University of Chicago. Selected Papers. no. 49.

[6] United Nations Documents (1974): Declaration on the Establishment of a New International Economic Order. Resolution adopted by the General Assembly A/RES/S-6/3201. Distr: General 1 May 1974.

[7] OECD - Centre for Entrepreneurship, SMEs and Local Development (2009): The Impact of the Global Crisis on SME and Entrepreneurship Financing and Policy Responses Contribution to the OECD Strategic Response to the Financial and Economic Crisis. Turin Round Table, Italy. 26-27 March 2009. 7-19 p.

[8] Wieczerzynska B. (2009): Kryzys w przedsiebiorstwie, CeDeWu, Warszawa. in: Jaworski (2012): Financial Management in a Small Enterprise in Economic Crisis. Gdansk School of Banking. 
[9] World Bank's Enterprise Analysis Unit (2015): Small and Medium Enterprises (SMEs) Finance. The World Bank Group. http://www.enterprisesurveys.org

[10] Doove S., Gibcus P., Kwaak T., Smit L., Span T (2014): Survey on the access to finance of enterprises (SAFE) . European Central Bank - Analytical Report . Brussels.

[11] The European Banking Authority (EBA): https://www.eba.europa.eu/

[12] Tajti Zs. (2011): A bázeli ajánlások és a tőkemegfelelési direktíva (CRD) formálódása. Hitelintézeti Szemle. X. évf. 5 sz.

[13] Franklin A., Thorsten B.- Carletti E. (2013): Structural changes in European financial systems: The impact of the regulatory framework on investment in the European Union. in: Kolev A., Tanayama T. Wagenvoort R. (ed. 2013): Investment and Investment Finance in Europe. European Investment Bank - Economics Department.

[14] Elliott, D., Salloy, S.,Santos, A. (2012). "Assessing the Cost of Financial Regulation" International Monetary Fund Working Paper, 12/233.

[15] TEGoVA (2003): Európai Értékelési Szabványok. Magyar Ingatlanszövetség-Füti Omega Kft. Budapest.

[16] Takács N. (2012): Határozzuk meg a likvidációs érték fogalmát! MAISz Ingatlanértékelői Bizottság részére küldött vitaanyag. Kézirat. Budapest. 